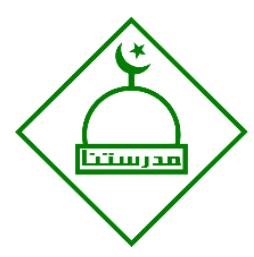

Madrosatuna: Jurnal Pendidikan Guru

Madrasah Ibtidaiyah

Volume 3 Nomor 2 ( 2020 )

http://jurnal.iailm.ac.id/index.php/madrosatuna

ISSN Cetak: 2656-4793

\title{
Analisis perkembangan moral anak melalui pembelajaran aqidah akhlak di MI MA'ARIF Candran
}

\author{
Seka Andrean ${ }^{1}$, Maemunah $^{2}$ \\ Mahasiswa Pascasarjana Universitas Islam Negeri Sunan Kalijaga Yogyakarta, Indonesia \\ Dosen Doktoral dan Pascasarjana Universitas Islam Negeri Sunan Kalijaga Yogyakarta, Indonesia \\ sekaandrean28@gmail.com, monah030973@gmail.com
}

\begin{abstract}
ABSTRAK
Kegiatan pembelajaran yang dilaksanakan oleh guru sebaiknya dapat menciptakan suasana belajar mengajar yang menyenangkan dan efesien. Sedangkan di sisi yang lain, kegiatan pembelajaran juga wajib diarahkan kepada perkembangan moral seorang anak agar memiliki kepribadian yang baik. Penilitian ini bertujuan untuk mengetahui perkembangan moral anak melalui pembelajaran aqidah akhlak di MI Ma'arif Candran. Subjek penelitian ini adalah peserta didik maupun guru MI Ma'arif Candran. Pendekatan yang digunakan dalam penilitian ini adalah pendekatan kualitatif, dengan menggunakan metode deskriptif. Hasil penelitian ini menunjukkan bahwa dalam perkembangan moral anak melalui pembelajaran aqidah akhlak yang dilaksanakan oleh guru di MI Ma'arif Candran ini adalah dengan menyusun perencanaan pembelajaran yang menyesuaikan dengan situasi, karakteristik siswa serta potensi peserta didik dengan memakai metode dan strategi yang terdiri dari: metode pembiasaan, metode keteladanan, metode nasehat, metode mekanisme kontrol, dan sistem sangsi.
\end{abstract}

Kata Kunci: Perkembangan, Moral, Pembelajaran Aqidah Akhlak.

\section{Analysis of moral development of children through learning aqidah akhlak at MI Ma'arif Candran}

\begin{abstract}
Learning activities performed by teachers should be able to create a fun and efficient teaching and learning atmosphere. On the other hand, learning activities are also required to be directed to the moral development of a child in order to have a good personality. This training aims to determine the moral development of the child through the study of the sexual Aqidah in MI Ma'arif Candran. The subject of this study was the students and teachers of MI Ma'arif Candran. The approach used in this research is a qualitative approach, using a descriptive method. The results of this study showed that in the moral development of the child through the study of sexual Aqidah implemented by the teacher at MI Ma'arif Candran is to develop a learning plan that adjusts to the situation, the characteristics of students and the potential of students by using methods and strategies consisting of: Habituation methods, methods of ethics, methods of advice, control mechanisms, and sanctions.
\end{abstract}

Keywords: Moral Development, Learning Aqidah Akblak.

\section{PENDAHULUAN}

Dalam pembangunan bangsa, pendidikan adalah salah satu aspek yang paling penting untuk menunjang sebuah keberhasilan bangsa. Dengan pendidikan yang berkualitas, maka suatu bangsa akan menatap sebuah masa depan yang cerah. Pendidikan juga sebagai usaha dalam 
membimbing dan mengembangkan kepribadian seseorang, baik itu berkaitan dengan prinsip ruhaniyyah ataupun berkaitan dengan prinsip jasmaniyyah (Ilahi dan Ratri 2012, 25). Sebuah pendidikan bisa dilaksanakan dengan upaya yang baik dan terstruktur agar membuat suasana belajar yang nyaman serta prosedur pembelajarannya bisa dilakukan dengan baik, agar anak didik bisa lebih aktif dalam mengembangkan kemampuannya untuk mempunyai energi spiritual kereligiusan, penanganan diri, jati diri, pandai dalam budi pekerti, serta keterampilan yang dibutuhkan olehnya, para masyarakt, segala bangsa, dan negara (Munandar 2012, 6). Hal demikian, sekolah atau madrasah ialah lembaga yang sangat urgent dalam menjunjung fungsi dari pendidikan tersebut supaya dapat tercapai. Dengan sekolah juga bisa mengembangkan seluruh potensi peserta didik dan membangun moral peserta didik tersebut..

Untuk mencapai tujuan pendidikan tersebut sudah pasti saling berkaitan eratt dengan peran guru yaitu sebagai pendidik. Guru disini dituntut sanggup dalam menyampaikan kejelasan tentang tujuan dari pendidikan dan tata cara dalam bersikap yang baik. karena mendidik ialah suatu aktifitas yang didalamnya menyampaikan berbagai pengajaran dan pembelajaran untuk siswa (peserta didik), membuat mereka sanggup mencerna atau menangkap segala sesuatu. Kemudian dengan pemahaman yang sudah dimilikinya tersebut maka dia bisa mengembangkan kemampuannya dengan cara mengaplikasikan sesuatu tersebut yang telah di perolehnya. (Kurniawan 2015, 122).

Perbincangan tentang seorang guru selalu memberikan daya tarik tersendiri, sebab guru merupakan kunci dari pendidikan. Guru mempunyai pekerjaan dan tanggung jawab paling penting dalam upaya tercapainya keberhasilan kegiatan belajar mengajar yang baik dalam kelas. Artinya, hal ini telah terjadi komunikasi secara tidak langsung antara guru kepada siswanya dan juga terjadi interaksi diantara keduanya selama kegiatan belajar mengajar tersebut memberikan efek yang baik bagi kesuksesan peserta didiknya (Pamuji, 2017: 236). Tenaga pendidik (guru) sebagai salah satu bagian dari bidang dunia pendidiikan maka seorang pendidik dituntut untuk dapat memberikan peran yang aktif dan meletakkan kedudukannya sebagai seorang tenaga pendidik yang berprofesional, serta tidaklah semata-mata sebagai tenaga pendidik yang hanya memberikan ilmu pengetahuannya saja, namun juga harus dapat menjadi seorang pendidik dan pembimbing yang mampu dalam menyampaikan arahan serta menuntun peserta didik ketika sedang belajar (Hadari, 2015: 123). Oleh karena itu, setiap tenaga pendidik (guru) seyogyanya melakukan pekerjaan dan tanggung jawabnya tersebut secara baik serta optimal. Selain sanggup dalam membentuk interaksi yang baik kepada siswa, guru juga dituntut dapat mencerna baik dari segi individual anak maupun kebutuhan khusus. Namun penting juga diketahui bahwasannya ada beberapa aspek yang rumit atau tidak bisa dirubah dalam pribadi anak, yaitu aspek genetik. Oleh 
karena itu, pendidikan ditujukan guna memfasilitasi seluruh anak dengan lingkungannya dan memberikan bimbingan dalam belajar supaya anak tersebut dapat mengembangkan jati dirinya sesuai dengan ukuran genetisnya. Sedangkan jika dilihat dari sisi yang lainnya, kegiatan belajar mengajar juga perlu ditujukan kepada perkembangan moral bagi pribadi seorang anak.

Perkembangan moral memiliki bagian kecerdasan dan bagian impulsif, seorang anak diwajibkan untuk mempelajari segalanya termasuk yang benar maupun yang salah. Pada usia ini perkembangan moralnya masih termasuk kedalam tingkatan paling bawah. Hal ini dikarenakan intelektual yang berkembang pada usia dini belumlah meraih point-point ketika anak tersebut bisa belajar, memahami, ataupun mengaplikasikannya dengan asas-asas absurd mengenai hal benar dan yang tidak benar. Diapun tidak mempunyai dukungan agar mematuhi peraturannya dikarenakan tidak tahu manfaatnya sebagai bagian dari kelompok sosiall. Karena tidak sanggup memahami persoalan standart moral, seluruh anak perlu belajar bersikap moral dalam berbagai kondisi yang terkhusus. Dia hanyalah mempelajari bagaimana berlaku tanpa harus tahu kenapa. Permulaan masa anak-anak ini disimbolkan oleh Piaget dengan sebutan "moralitas melalui paksaan”. Kemudian, ketika usia mereka sudah cukup besar, maka ia perlu diberikan penjelasanpenjelasan mengenai kenapa yang ini disebut benar dan yang ini disebut salah. (Dwiyanti 2013, 162-63). Berkaitan dengan hal ini, maka dirapkan agar anak disik mampu memiliki standar yang baik serta bersikap sesuai dengan standarnya juga baik atau buruk berdasarkan pada ketetapan agama. Perkembangan nilai moral ini dilakukan dengan integrasi dalam sebuah mata pelajaran yang ada di sekolah. Mata pelajaran ini ialah Aqidah Akhlaq yang difokuskan untuk membantu perkembangan nilai moral.

Aqidah Ahlak adalah salah satu mapel (mata pelajaran) disekolah yang mempunyai andil paling tinggi dalam membantu mendorong siswa supaya dipelajari kemudian dipraktikkan aqidahnya tersebut dalam wujud kehidupan sehari-hari agar supaya menjadi kebiasaan diri untuk berbuat akhlak yang terpuji dan menjauhkan dari akhlak yang tercela. Akblakulkarimah ini sangatlah penting untuk diterapkan oleh peserta didik dan menjadi kebiasaan dalam kehidupan pribadi, masyarakat dan bangsa. Lebih-lebih dalam rangka mencegah efek buruk dari masa disrupsi dan kritis multidimensional yang menerpa bangsa dan Negara Indonesia kita (Putra 2018, 151). Oleh karena itu Aqidah Akhlak menjadi fokus dalam penelitian ini.

Sementara itu, di MI Ma'arif Candran, Sidoarum, Sleman, D.I Yogyakarta sebagai lembaga sekolah yang berbasis agama Islam ternyata masih memiliki permasalahan perihal moral peserta didik. Contohnya, kemrosotan moral, rasa tidak percaya diri, perlakuan licik, mengabaikan aturan yang sudah ditetapkan, ketidak toleransian, penggunaan perkataab yang tidak sopan, dan kurang disiplin Dengan masalah yang telah diungkapkan, peneliti berharap bahwa semua masalah yang 
terjadi pada siswa dapat ditangani dengan baik dengan upaya maksimal dari guru, orang tua, masyarakat maupun pemerintah, agar nantinya siswa menjadi generasi penerus bangsa yang bukan hanya hebat dalam ilmu pengetahuan namun juga hebat dengan pribadi yang berkarakter kuat.

Dengan latar belakang tersebut, maka rumusan masalahnya adalah bagaimana perkembangan moral anak melalui pembelajaran aqidah akhlak di MI Ma'arif Candran.

\section{Perkembangan Moral}

Perkembangan merupakan proses tranformasi yang liberal dan berkesinambungan dalam diri individual yang dimulai pertama kali keluar dari perut (lahir) hingga tutup usia (mati) atau yang disebut dengan "the progressiveand continous change in the organism from birth to death". Perkembangan dapat diartikan juga sebagai perubahan kedewasaan dalam kematangan diri seseorang yang dirasakan oleh seseorang secara sistematiss, progesif, dan berkesinambungan dengan jasmaniyyah dan rohaniyyah. (S Yusuf 2016, 24).

Moral secara bahasa “mores" ialah jamak dari “mos” yaitu adat istiadat (kebiasaan). KBBI (Kamus Besar Bahasa Indonesia) menyatakan moral ialah penetapan bagus tidaknya perbuatan yang dilakukan oleh seseorang. Moral dalam istilah sudah biasa digunakan sebagai penentu batasan suatu sikap, tingkah laku, sifat dan budi pekerti yang dinyatakan sebagai yang benar dan tidak benar, kemudian yang baik dan buruk, terus antara masih layak atau malah sudah tidak layak, taat maupun tidak taat. Moral ialah suatu peraturan atau tatacara dalam hidup yang bercirikan mengatur atau mengikat (normatif) yang telah turut serta dengan kita seiring dengan berjalannya usia kita, sehingga titik tekan "moral" ialah sebuah peraturan normatif yang harus ditanamkan dan diabadikan dengan sengaja, baik dari keluargan, dari lembaga pendidikan, dari lembaga pengajian, ataupun dari komunitas lainnya yang berkaitan dengan masyarakat. (Dwiyanti 2013, 163)

Perkembangan moral ialah pergantian nalar, rasa, dan tingkah laku yang mengenai dengan standar tentang yang baik dan yang buruk. Dalam berkembangnya moral mempunyai perspektif intra personal, dalam memanage kegiatan orang ketika seseorang tersebut turut berinteraksi sosial dan persepektif interpersonal yang mengelola interaksi sosial serta yang menyelesaiankan konflik. berkembangnya moral berkaitan dengan aturann dan ketentuan dalam apa saja yang perlu dilaksanakan oleh orang tersebut dalam melakukan interaksi dengan orang yang lain.(Santrock, John W 2007).

Kohlberg (dalam Monks, dkk., 2002) menyatakan bahwa perkembangan insan kamil yang melewati enam stadium kemudian stadium ini akan selalu dilewati pada tiap-tiap anak, hal ini 
bersifat universal, artinya dimana pun keberadaannya akan selalu ada, barangkali bukan pada barisan yang serupa akan tetapi perkembangannya akan melewati barisan tersebut.

Menurut Kohlberg perkembangan moralitas terbagi menjadi tiga level yang pada masingmasinya terbagi lagi menjadi dua stadium sampai semuanya menjadi enam stadium. Adapun langkah-langkah pada masing-masing tersebut mempunyai karakteristik sendiri, sebagimana yang ditampakkan pada tabel 1 dibawah ini.

Tabel 1. Perkembangan Moral Kohlberg

Tingkatan

1. Nalar moral prakonvensional. 1. rasa taat dan takut terhadap sanksi. sebuah Berdasarkan kepada objek yang ada pada prilaku yang dianggap benar maka tidak perlu luar diri individunya sendiri dalam diberikan sanksi namu jika prilaku tersebut mengukur yang benar ataupun yang tidak dianggap salah amka harus diberikan sanksi benar.

2. Nalar moral yang konvensional. berdsarkan pada harapan sosial, yakni suatu prilaku yang dianggap benar apabila sesuai dengan peraturan yang telah berlaku dalam bermasyarakat. oleh sebab itu, pada tiap-tiap orang dituntut untuk taat dan nurut terhadap otoritas dikarenakan otoritaslah yang berkuasa.

2. Orientasi egoistik. Ini juga berdasarkan kepada obyek ataupun peristiwa yang terjadi diluar diri individunya, akan tetapi telah memperlihatkan alasan atas prilakunya, contohnya pada tindakan pencurian maka hal tersebut dianggap, namun dapat diberi maaf jika dengan alasan untuk memenuhi segala kebutuhannya sendiri ataupun kebutuhan untuk orang yang disayanginyas. Stadium ini juga diberi nama stadium hedonistiik instrumental..

3. Orientasi pada siswa yang bagus. Seorang siswa menganggap suatu prilaku itu bagus jika dia bisa membuat orang lain senang, jika ia bisa dilihat sebagai perempuan maupun laki-laki yang baik juga, yakti apabila ia bisa berprilaku seperti yang masyarakat atau orang lain harapkan.

4. Orientasi mengabadikan otoritas dan peraturan sosial. Seorang siswa mengetahui peraturan sosial yang sudah berlaku merupakan hal yang perlu dipelihara dan diabadikan. Seorang akan dianggap bermoral jika dia sudah "melakukan tugasnya" dan kemudian bisa dilestarikan peraturan tersebut dan sistem sosial tersebut.

3. Nalar moral yang post konvensional. 5. Orientasi control legalistis. Mencerna Peraturan yang ada pada masyarakat aturan-aturan yang sudah berlaku didalam dipandang tidaklah absolut, namun masyarakat itu ialah sebuah kesepakatan antara dianggap relatif; karena bisa digantikan diri sendiri dengan masyarakat. Seseorang wajib oleh orang yang lain. mematuhi segala tugas-tugasnya, namun juga 
sebaliknya masyarakat wajib mempertagung jawabkan kemakmuran seseorang. Aturanaturan yang ada dalam masyarakat itu disebut dengan subjektif.

6. Orientasi berdasarkan atas asas dan juga hati nuraninya sendiri. Aturan-aturan serta norma ialah subjectif, begitu juga dengan pemisahnya ialah tidak menentu dan bersifat subjektif. Melihat hal ini maka tingkatan pada penilaian prilaku moral ialah konsiensia dirinya sendiri, prinsipnya lepas dari semua norma yang sudah ada. Prinsip inilah yang dikatakan oleh kohlberg bahwa aspek moral yang universal, yakni norma moral yang pada dasarnya sudah ada didalam hati nurani pribadinya sendiri

Kegiatan perkembangan moral seorang anak bisa langsung melewati beberapa tehnik, yaitu : a) Pendidikan secara langsung, yakni penanaman pemahaman mengenai prilaku yang dianggap baik dan tidak baik, prilaku baik dan buruknya dari orang tua, tenaga pendidik sendiri, bahkan dari orang-orang yang sudah dewasa. b) Identifikasi, yakni tahap mengidentifikasikan atau menirukan gaya ataupun prilaku moral seseorang yang menjadi favoritnya. c) trial and error, yakni tahap berkembangnya prilaku moral seseorang dengan percobaan. Prilaku tersebut bisa memberikan sanjungan atau apresiasi maka harus teruslah untuk dikembangkan. Sedangkan prilaku yang membawa berbagai ancaman hukuman maka harus segera dihentikan.

Adapun tujuan dari mengembangkan kemampuan nilai moral anak ialah: 1) Menciptakan suasana agamis yang kondusif. Melakukan amalan nilai-nilai religius itu yang paling penting berkaitan dengan akhlak mulia, seperti taat dalam ibadah mahdzah (contoh: sholat), kepatuhan kepada pekerjaan, menjalankan amanah, bertanggung jawab, dan memiliki sikap yang jujur, menjaga kebersihan lingkungan, serta menjalin tali silaturrahim antar persaudaraan. 2) memelihara kondisi sosio-emosional pada anak. Sekolah dianggap sebgai lingkungan yang mempunyai harapan besar agar bisa mengembangkan kompeten-kompeten sosial dan emosional pada peserta didik. Oleh karena itu sekolah sendiri harus berfungsi sebagai suatu latar belakang yang mendorong berkembangnya nilai moral pada anak. 3) Menciptakan budaya yang bersifat intruksional. Maksudnya ialah lebih ke menunjukkan pada sikap mental, sikap kebiasaan, serta sikap yang berkaitan dengan kegiatan pendidikan termasuk juga dalm segi kejujuran, kerajinan, dan lain sebagainya. sebab itu, guru harus menunjukan bahwa dirinya adalah sebagai panutan yang di gugu dan ditiru dalam memberkan syuri tauladan yang baik kepada para peserta didiknya. (Azhar dan Sa’idah, 2017: 79) 


\section{Pembelajaran Aqidah Akhlak}

Aqidah adalah masdar dari perkataan "aqoda, ya'qidu, 'aqdan-, aqidatan” yang artinya adalah kesimpulan, pengikatan, bersangkutan, sebuah perjanjian dan kuat (koko). Sedangkan aqidah secara teknis diartikan sebagai iman. Kewajiban dalam pendidikan berkarakter selain memberikan pelajaran mana yang dikategorikan tingkat kebaikan dan yang dikategorikan masuk ke tingkat keburukan, disini malah yang di fokuskan ialah tahapan-tahapan penanaman diri pada kebiasaankebiasan (babituation) kepada sesuatu yang baik. Alhasil yang diharapkan dari individu dapat memahami mengenai nilai-nilai dalam kebaikan dan nilai-nilai dalam keburukan, sanggup merasakan nilai yang baik dan ingin melaksanakannya dalam sebuah panutan serta kepercayaan. Dengan begitu tumbuhlah sebuah kepercayaan yang ada didalam hati, sehingga aqidah disini maksudnya adalah sebuah kepercayaan atau keyakinan yang sudah terikat didalam hati (Andi Banna, 2019: 103). Suatu Aqidah diumpamakan sebagai pondasi bangunan yang kokoh. Sehingga aqidah perlu disusun sedemikian rupa dan dibangun sebelum dibandingkan dengan bagian-bagian yang lainnya. Aqidah disini juga perlu didirikan dengan kokoh dan kuat supaya tidak rentang goyah yang kemudian bisa mengakibatkan bangunan tersebut menjadi roboh. Bangunan disini maksudnya ialah islam, keseluruhan dan kesempurnaan.

Pembahsan tentang Aqidah sudah pasti kurang lengkap jika tidak di barengi dengan akhlak. Wujud dari pencapaian dan indikasi diri dari aqidah sesorang disebut dengan Akhlak. Adapun Akhlak sendiri berasal dari lughotul ngarobiyyah yakni bentuk jamak dari “kbulukun”, berarti karakter, tabiat, kebiasaan, peradaban yang bagus, dan terakhir adalah agama. (Subahri 2015, 169) Sedangkan akhlak secara bahasa artinya adalah penciptaan. Dalam pembahasan mengenai agama, akhlak berarti kepribadian, budi pekerti, bawaan, etika, atau sikap seseorang (Ahmad Bangun Nasution And Rohani Hanun Siregar, 2013: 30).

Dengan demikian siswa sekolah dasar harus memiliki nilai-nilai akhlak, seperti sebagai berikut: a) mempunyai al-akhlaq al-karimah yang didalamnya terdiri dari: kedisiplinan, hidup yang bersih, kemudian ramah tamah, lalu sopan dan santun, mensyukuri nikmat, hidup apa adanya, tetap tidak sombong, kejujuran, sikap rajiin, sikap percaya kepada diri sendiri, sikap menyayangi, patuh dan ta'at, damai, saling bantu membantu, hormat menghormati, selalu amanah dalam menjalankan kewajibannya dan sebagainya. b) menjauhkan akhlak yang tidak baik yang didalamnya terdiri atas: perkataan buruk, memiliki hidup yang tidak bersih, berbohong, memiliki sifat sombong dan pemalas, durhaka kepada orang tua, berkhianat, iri dang denki, dan sebaginya. c) etika Islamiah yang didalamnya terdiri atas: etika kepada dirinya sendirii (seperti: etika saat 
memakan dan meminum, saat mmebersihkan bada, saat memejamkan mata, saat di wc, saat berkomunikasi kepada orang lain dan sebagainya (Didik Efendi, 2019: 12).

Berkaitan dengan hal atas, akhlak secara hakikat ialah suatu situasi atau bawaan yang sudah masuk kedalam jiwa seseorang kemudian menjadi kepribadian. Dari sinilah kondisi jiwa bergerak dan memberikan dorongan yang menunjukkan bahwa dalam melakukan perbuatan tidaklah selalu menggunakan pikiran.

Dengan demikian dapat diketahui bahwa aqidah akhlak adalah usaha yang nyata dan tersusun dalam mempersiapkan siswa atau siswa agar saling kenal, saling memahami, saling menghayati dan saling beriman kepada tuhan yang maha Esa dan mengaplikasikannya kedalam sikap akhlak yang terpuji didalam hidup sehari-hari yang didasarkan atas Al-Qur'an dan Al-Hadits dengan melewati proses pembimbingan, memberikan pelajaran dan ujian, serta menggunakan pengalamaan yang sudah-sudah. Dibersamai dengan tuntutan yang menekankan agar saling hormat-menghormati sesama pemeluk agama lain dan menjaga hubungan toleransi dengan rukun sesama kaum beragama didalam masyarakat sehingga dapat diwujudkan dalam sebuah kestuan dan perstuan bangsa terutama bangsa indonesia.

Pembelajaran akidah akhlak memiliki tujuan menunjukan dan meningkatkan keimanan siswa, sehingga dapat dioutputkan ke dalam bentuk aplikasi kehidupan sosial. Adapun implikasinya terhadap perilaku individu sebagai manusia beragama yakni teraplikasikannya perilaku terpuji melalui pembelajaran dan pemahaman melalui pencarian pengetahuan, kemudian menghayatinya, sehingga memberikan pengalaman kepada peserta didik terkait akidah dan akhlak. Selain itu, visi dari mata pelajaran akidah akhlak ialah mebentuk muslim yang berkembang dan memiliki kualitas iman juga taqwa kepada Pencipta, sehingga berdampak dalam menjalankan kehidupan bermasyarakat, berbangsa dan bernegara sekaligus pandangan hidup panjang untuk masa panjang besok.

Pada umumnya dalam melaksanakan pembelajaran meliputi dari pendidik (guru) dan peserta didik (siswa). Dengan kalimat lain pembelajaran ialah proses berlangsungnya interaksi yang efisien dan efektif antara seorang guru dengan seorang murid.

\section{Metode Penelitian}

Metode penelitian ini, peneliti menggunakan penelitian dalam pendekatan kualitatif. Dengan menggunakan metode deskriptif (Wina Sanjaya, 2013: 47). Penelitian ini mendeskripsikan tentang Analisis perkembangan moral anak melalui pembelajaran aqidah akhlak di MI Ma'arif Candran, Sidoarum, Sleman, D.I Yogyakarta. Fokus dari penelitian ini adalah bagaimana perkembangan moral peserta didik melalui pembelajaran aqidah akhlak di MI Ma'arif 
Candran. Subjek penelitian ini ialah mengacu pada individu-individu baik dari individu peserta didik maupun individu guru yang berada MI Ma'arif Candran. Sumber data dalam penelitian ini diambil dari pendidik dan peserta didik serta dokumen-dokumen yang ada disana sebagai pedoman guru dalam menyusun kegiatan pembeljaran dengan terkhusus dalam perkembangan moral anak melalui program pembelajaran Aqidah Akhlak. hal ini juga serupa dengan pendapatnya Moloeong (2017: 7) bahwa "sumber data utama dalam penelitian kualitatif ialah kata-kata, dan tindakan, selebihnya adalah data tambahan".

Teknik dalam pengumpulan data ini diutamakan memakai wawancara, observasi dan dokumentasi dipakai untuk tambahan pada data. Yakni mewawancarai guru Aqidah Akhlak MI Ma'arif Candran berkaitan dengan perkembangan moral pada peserta didik. Kemudian teknik observasi ini dilakukan dengan cara mengobservasi aktifitas guru dalam mengembangkan moral pada peserta didik dalam kegiatan belajar mengajar baik di kelas ataupun di luar kelas. Sedangkan teknik dokumentasi dilaksanakan dengan mencari dan mengumpulkan dokumen-dokumen berkaitan dengan perencanaan pembelajaran yang telah disusun dengan khusus untuk memperoleh data mengenai pengembangan moral dan agama tersebut. Penggunaan teknik wawancara, merujuk pada pendapat (Sugiyono, 2017) yang berbunyi "Secara umum ada dua jenis teknik wawancara yaitu teknik wawancara terstruktur dan tak terstruktur. Tujuannya adalah untuk menyajikan konstruksi saat sekarang dalam suatu konteks mengenai para pribadi, peristiwa, aktivitas, organisasi dan sebagainya".

Dalam pelaksanaannya, peneliti memakai teknik wawancara tidak terstruktur. Dalam wawancara tidak terstruktur ini beberapa pertanyaan wawancara bisa berubah menyesuaikan kondisi, tidak harus serupa persis dengan acuan yang sudah dirancang, akan tetapi fokus pada permasalahannya tidak berubah. Kemudian seluruh hasil data yang didapat dari wawancara itu diingat dan dicatat secara terstruktur. Apabila masih terdapat kekurangan atau sesuatu yang masih dibutuhkan, atau datanya masih kurang lengkap, maka peneliti bisa menemui guru yang bersangkutan kembali untuk meminta diwawancarai lagi dengan waktu yang berbeda. Kemudian untuk pengumpulan data dengan teknik observasi cukup mengacu pada pendapat saja (Sugiyono, 2017) mengatakan bahwa "observasi berperan pasif mengenai perilaku dan kondisi lingkungan penelitian bisa dilakukan secara formal maupun informal. Secara formal dapat diamati misalnya pertemuan, kegiatan kelas, dan sebagainya".

\section{Hasil dan Pembahasan}

Dalam perkembangan moral anak di MI Ma'arif Candran, Sidoarum, Sleman, D.I Yogyakarta lebih mendapatkan perhatian dan kasih sayang yang khusus dari gurunya. Yang mana 
guru disini harus bekerja lebih keras dalam memberikan pembimbingan dan pengarahan pada peserta didik supaya potensi-potensi moral yang anak-anak miliki bisa berkembang secara baik. Selain itu, guru juga harus diberikan bimbingan dan pengarahan oleh kepala sekolah dilakukan dengan tujuan untuk memaksimalkan kompetensi yang sesuai yang dimiliki oleh guru dalam peningkatan kinerja guru.

Seperti yang kita ketahui bahwasannya awal masa umur sekolah dasar seorang anak akan menjadi sosok yang peniru ulung atau yang disebut dengan "imitative". Peserta didik lebih menangkap pelajaran dari apa yang mereka ketahui secara langsung dari lingkungan di sekitarnya. Lebih menirukan orang lain karena itu bisa jadi alasan yang nomor satu dalam berkembangnya pengetahuan intelektual pada anak, karena meniru disini menjadi salah satu langkah yang efektif dan efisien untuk memperoleh pelajaran baru. Oleh karena itu sangat dibutuhkan upaya dan usaha dari seorang guru untuk bisa membantu mengembangkan nilai-nilai moral atau akhlakul karimah yang telah dimiliki oleh anak terutama anak yang berada dikelas bawah, sepertti kelas 1 sampai 3.

Anak-anak pada masa kelas bawah (kelas 1-3) Madrasah Ibtidaiyah masih masuk kedalam kategori usia imitasi “imitative age”, yakni anak-anak memiliki lebih ke sering mengikuti cara orang dalam berbicara atau bersikap dan apapun itu yang ada dilingkungan sekitarnya. Pada tiap-tiap anak mempunya potensi bawaan dari lahir yang sifatnya laten salah satunya ialah potensi pada nilai moral kereligiusan. Nilai moral ini sangatlah berperan tinggi dan sangat berpengaruh untuk kehidupannya. Nilai moral disini dujadikan sebagai landasan dalam melewati dan manaungi makna kehidupan (Azhar dan Sa’idah, 2017: 79).

Nilai-nilai moral yang dibiasakan di MI Ma'arif Candran adalah sikap kedisiplinan, sikap kejujuran, sikap bertanggung jawab, sikap ikhlas, sikap toleransi, saling hormat-menghormati, dan saling peduli terhadap lingkungan. Dengan demikian nilai-nilai itu ditanamkan lewat integrasi budaya sekolah, mata pelajaran, dan kegiatan ekstrakurikuler.

Dalam merencanakan pembelajaran pada aqidah akhlak sendiri yang telah dirancang oleh seorang guru ialah dengan menyusun perencanaan dalam pembelajaran berupa strategi dan juga metode dalam mengembangkan nilai moral kepada peserta didik dan pemakaian alat belajar mengajar dan juga pola belajarnya mengacu pada yang dituju yakni tujuan. Yang didalam tujuan belajar mengajar ini tidaklah hanya bisa memperoleh tambahan wawasan dari peserta didiknya sendiri berupa ilmu pengetahuannya, melainkan juga bisa merubah tingkah laku dan sikap mereka supaya kelak mereka bisa mempunyai kepribadian yang lebih baik. Hal ini mengacu pada pendapat Kimble dan Garmezi (Muhammad Thobroni dan Arif Mustofa 2011, 18) mengenai pengertian belajar bahwasannya belajar ialah suatu perubahan prilaku yang secara langsung dapat 
permanen, hal ini bisa terjadi karena hasil tersebut berasal dari sebuah sesuatu yang pernah dialami. Oleh karena itu, penyusunan pembelajaran yang telah dirancang guru itu hendaknya kondisinya disesuaikan dengan karakteristik dan kesanggupan pada siswa, namun tetaplah tidak terlepas dari pedoman kurikulum dalam pembelajaran yakni yang berdasarkan pada RPP dan silabus. Sehingga selama kegiatan belajar mengajar berlangsung maka akan lebih memudahkan guru dalam menjelaskan dan memberikan materi yang mana didalamnya berisi tentang pendidikan nilai moral.

Dengan dilakukannya perencanaan terlebih dahulu maka kegiatan belajar mengajar akan berjalan dengan semestinya dan pastinya serupa dengan tujuannya seperti yang diinginkan, yakni: anak didik sanggup memahami pelajarannya dan bisa mengaplikasian materi tersebut dalam kebiasaan setiap hari sampai nilai moral yang bagus tersebut bisa terbentuk. Sebuah perencanaan tak pernah lepas dari sebuah alat yang digunakan dalam belajar mengajar, trik belajar mengajar dan juga kondisi dalam kelas yang dilaksanakan guru ketika berlangsungnya kegiatan pembelajaran. Karena peran seorang guru di sini sebagai motivator dan fasilitator untuk anak didinya. Oleh sebab itu, guru sangatlah berperan dan mempengaruhi didalam berkembangnya nilai-nilai moral pada anak didik. Kemudian seorang guru juga dituntut untuk sanggup menyusun perencanaan dlam pembelajaran yang berkualitas dan semenarik mungkin, supaya anak didik dapat termotivasi untuk bisa meningkatkan belajarnya yang lebih baik lagi.

Sedangkan didalam penentuan pelajaran aqidah akhlak ini, diarahkan kepada perkembangan moral peserta didik itu sendiri. Mereka tidaklah hanya mendalami dari segi keintelektualannya saja, melainkan juga mendalami pada nilai-nilai moral anak didik. Oelh karena itu dalam penerapannya seorang guru dituntut untuk sanggup memberikan pelajaran yang bermakna ketika berlangsungnya kegiatan pembelajaran. Seorang guru dalam menyampaikan pembelajarannya hendaklah memakai segala macam sumber belajar kemudian dikaitkan dengan bahan yang akan digunakan. Disamping itu, keaktifan pada murid dalam kegiatan belajar mengajar hendaknya juga harus diperhatikan karena hal ini dapat menjadikan tolak ukur guru untuk melihat seberapa jauh anak didik sanggup menguasai materi yang diberikan yakni pelajaran Aqidah Akhlak. Secara konsep, pembelajaran ini mempunyai berbagai keterlibatan, diantaranya: Pertama, memerlukan usaha yang maksimal supaya kegiatan belajar mengajar dapat berlangsung dengan interaktif antara anak didik dengan sumber belajar yang disusun. Kedua, teruntuk siswa, dalam kegiatan belajar mengajar yang berlangsung dapat melakukan interaksi internal yang mengaitkan segala kemampuan yang punyanya dengan bersumber kepada yang telah direncanakan. Adapun sumber belajar dalam hal ini cukup beragam, diantaranya yaitu: 1) mata pelajaran yang sedang diajarkan yang didalamnya mengandung nilai-nilai. 2) fasilitator adalah 
fungsi yang dimiliki oleh gur. 3) materi dalam pebeljarannya bisa berupa cetak maupun tidak cetak. 4) alat yang digunakan dalam pembelaran. (5) langkah yang digunakan dalam proses belajar. 6) situasi lingkungn sossial, budaaya, spirituall, dan alam yang dapat memberikan perubahan pada prilaku anak didik kearah yang lebih baik lagi.

Ketiga, dalam kegiatan ini juga membuka kesempatan agar dapat menentukan dan mengembangkan cara belajar mengajar yang mempunyai kesempatan sangat bagus untuk mencapai tujuan. Dalam kegiatan pembelajaran inipun mengacu pada pernyataan dari Marzuki $(2015,11)$ bahwasanya moral sangat identk pada akhlak, oleh karena itu moral juga termasuk dari nilai tingkah laku seseorang yang universal yaitu yang terdiri dari semua aktifitas seseorang tersebut, baik yang kaitannya dengan sang pencipta, pribadi, atau antar manusiawi, bakan lingkungan sekitarnya, yang berwujud didalam pemikiran, tindakan, rasa, ucapan, dan tingkah laku atas dasar norma-norma dalam keagamaan, hukum etika, budaya dan adat istiadat.

Dari uraian diatas, bahwa perkembangan moral peserta didik yang dilaksanakan oleh guru melalui pembelajaran aqidah akhlak ialah memakai tehnik ajar yang sudah sama dengan berkembangnya karakter pada siswa, yakni dilakukan mengunakan tehnik kebiasaan dengan melakukan sesuatu yang sederhana berkaitan dengan materi pembelajaran aqidah akhlak, seperti: 1) jika saling bertemu maka dibiasakan mengucap salam. 2) sebelum pelajaran dimulai maka terlebih dahulu melakukan doa bersama. 3) dibiasakan berjabat tangan dengan gurunya ketika hendak masuk class. 4) Membaca basmallah untuk memulai pelajaran, kemudian sholawat Nariyah dan surat-surat pendek. 5) Bergaul dengan baik sesama kerabatnya di kelas. 6) buanglah sampah pada kotak sampah. 7) pas mau masuk kelas maka di biasakan untuk mengucap salam. 8) ketika hendak meninggalkan ruang kelas pun juga dibiasakan untuk mengucapkan salam. 9) dan megajarkan adab dalam ucapan, etika belajar, etika makan, etika minum, dan sebagainya.

Selain itu, dalam perkembangan moral siswa, guru harus bisa menjadi suri tauladan bagi muridnya agar terhindar dari tiruan yang sifatnya tidak baik untuk mereka, dengan melakukanhalhal yangsederhanasepertimembuang sampah pada tempatnya. dengan tehnik ini, ketauladanan dan penyampaian nasihat bisa dijadikan contoh sikap yang baik-baik untuk murid dan bisa menjadi kebiasaan dalam hidup mereka sehari-hari.

Searah dengan perkembangan moral anak melalui pembelajaran akidah akhlak yang dilaksanakan oleh guru kelas bawah (kelas 1-3) di MI Ma'arif Candran. Hal ini serupa dengan pendapat Aden (2011) yakni Quthb dan Abdullah Nasih 'Ulwan. Terdapat beberapa tehnik yang dapat dipakai dalam berkembangnya kemampuan nilai moral siswa yaitu teladan, kebiasaan, memberikan nasehat, mekanisme control, dan sistim hukuman atau qubah. Siswa yang bersifat lebih menirukan maka gurunya dituntutt agar supaya dapat menyampaikan suri tauladan beserta 
contoh-contoh tingkah laku yang bagus untuk murid, yang dibiasakan dalam keseharian serta mengawasi dan memberi arahan tingkah laku pada siswa.

Selaras juga dengan pernyataan dari Depdikbud dalam berkembangnya suatu nilai dan prilaku siswa bisa menggunakan tehnik yang bisa menjamin terbentuknya pembiasaan diri atas dasar nilai-nilai moral dalam Pancasila supaya siswa dalam menaungi kehidupan bisa sama dengan norma yang digunakan oleh masyarakat.

Penjelasan diatas serupa dengan pernyataan Prof. Dr. Syamsu Yusuf LN, M.Pd, dan Dr. Nani M. Sugandhi, yang merupakan 2 orang gurubesar dalam psikologi pendidikan di Indonesia, dalam karya buku "Perkembangan Peserta Didik" menyatakan bahwasanya cara agar nilai moral siswa berkembang yakni dengam menggunakan langkah-langkah yang bisa menumbuhkan suasana agamis yang kodusif, menyusun suasana sosio emossional, menciptakan kebiasaan dalam pembeljran, terfokus dalam kegiatan belajar mengajar, terfokus dalam program pembimbingan konselingg, dan terfokus pada exstrakurikuler, serta gotong royong dengan orang-orang yang bersangkutan.

Penjelasan diatas, bisa di ambil kesimpulan bahwaa dalam perkembangan moral melalui pembelajaran aqidah akhlak yang dikerjakan sama guru dikels bawah (kelas 1-3) MI Ma'arif Candran, Sidoarum, Sleman, D.I Yogyakarta saya anggap sudah dilakukan dengan optimal dan sudah sesuai dengan teori-teori yang disampaikan oleh Hurlock(1980) bahwasanya pembentukan prilaku tidak hanya dinyatakan dalam ucapan saja melainkan juga dinyatakan dalam perbuatan.

Hal tersebut bisa dijadikan sebagai pegangan baik dari guru ataupun orang tua bahwa perkembangan pada anak didik tidaklah jauh-jauh dari pengaruh lingkungannya sehingga guru dapat lebih peka untuk menambah kemampuan yang mengusai setiap sifat dalam berkembangnya siswa didik, bisa memberikan pengarahan dan memberikan bimbingan kepada siswa didiknya. Sehingga anak tersebut bisa mempunyai kepribadian yang terpuji, sebab kewajiban seorang pendidik bukanlah sekedar mengembangkan kemampuan yang sudah ada pada diri siswa tersebut, melainkan juga supaya siswa tersebut dapat bertumbuh menjadi kepribadian yang soleh dan solehah.

\section{Kesimpulan}

Perkembangan moral melalui pembelajaran Aqidah Akhlak di MI Ma'arif Candran, Sidoarum, Sleman, D.I Yogyakarta adalah: 1) jika saling bertemu maka dibiasakan mengucap salam. 2) sebelum pelajaran dimulai maka terlebih dahulu melakukan doa bersama. 3) dibiasakan berjabat tangan dengan gurunya ketika hendak masuk kelas. 4) Membaca basmallah untuk memulai pelajaran, kemudian sholawat Nariyah dan surat-surat pendek. 5) Bergaul dengan baik 
sesama kerabatnya di kelas. 6) buanglah sampah pada kotak sampah. 7) hendak mau masuk kelas maka di biasakan untuk mengucap salam. 8) ketika hendak meninggalkan ruang kelas pun juga dibiasakan untuk mengucapkan salam. 9) dan megajarkan etika dalam ucapan, etika belajar, etika makan, etika minum, dan sebagainya. Dalam perkembangan moral peserta didik dikelas bawah (kelas 1-3) di MI Ma’arif Candran, Sidoarum, Sleman, D.I Yogyakarta yang dilakukan oleh guru adalah dengan menyusun perencanaan pembelajaran yang menyesuaikan dengan kondisi dan situasi, karakteristik dan kesanggupan anak didik serta menggunakan metode dan strategi.

\section{DAFTAR PUSTAKA}

Aden R. 2011. Serba-Serbi Pendidikan Anak. Yogyakarta: Siklus.

Agus Wibowo. 2012. Pendidikan Karakter: Strategi Membangun Karakter Bangsa Berperadaban. Yogyakarta: Pustaka Belajar.

Azhar, Khoirul, dan Izzah Sa'idah. 2017. "Studi Analisis Upaya Guru Akidah Akhlak Dalam Mengembangkan Potensi Nilai Moral Peserta Didik di MI Kabupaten Demak." AlTA'DIB 10 (2).

Dwiyanti, Retno. 2013. "Peran Orangtua Dalam Perkembangan Moral Anak (Kajian Teori Kohlberg)," Juni.

Efendi, Didik. 2019. "Proses Pembentukan Aqidah Dan Akhlak Pada Siswa Sekolah Dasar Di Kota Jayapura." Al-Adrka: Jurnal Ilmiah Pendidikan Guru Madrasab Ibtidaiyah 9 (1): 9-20.

Hadari, Nawawi. 2015. Organisasi Sekolah dan Pengelolaan Kelas Sebagai Lembagas Pendidikan. Jakarta: CV. Haji Masagung.

Hurlock, Elizabeth B. 1980. Psikologi Perkembangan Suatu Pendekatan Sepanjang Rentang Kehidupan Edisi Kelima. Jakarta: Erlangga.

Ilahi, Muhammad Takdir, dan Rose Kusumaning Ratri. 2012. Revitalisasi pendidikan berbasis moral. Yogyakarta: Ar-Ruzz Media.

Kurniawan, Machful Indra. 2015. "Mendidik Untuk Membentuk Karakter Siswa Sekolah Dasar: Studi Analisis Tugas Guru Dalam Mendidik Siswa Berkarakter Pribadi Yang Baik." PEDAGOGLA: Jurnal Pendidikan 4 (2): 121-126-126.

Marzuki. 2015. Pengintegrasian Pendidikan Karakter dalam Pembelajaran di Sekolah. Yogyakarta: FIS Universitas Negeri Yogyakarta.

Monks, F.J., Knoers, A.M.P., Haditono, S.R. 2002. Psikologi Perkembangan: Pengantar dalam berbagai bagiannya. Yogyakarta: Gadjah Mada University Press.

Muhammad Thobroni, dan Arif Mustofa. 2011. Belajar \& Pembelajaran. Yogyakarta: Ar-Ruzz Media.

Munandar, Utami. 2012. Pengembangan kreativitas anak berbakat. Jakarta: Departemen Pendidikan \& Kebudayaan : Reneka Cipta.

Pamuji, Zuri. 2017. "Implementasi Manajemen Pembelajaran Ramah Anak Dalam Menanamkan Karakter Disiplin (Studi Pada Upaya Guru Kelas 1A Di MA Muhammadiyah Beji)." Yinyang: Jurnal Studi Islam Gender Dan Anak 12 (2): 235-55.

Putra, Purniadi. 2018. "Implementasi Pendidikan Karakter Dalam Pembelajaran Aqidah Akhlak (Studi Multi Kasus di MIN Sekuduk dan MIN Pemangkat Kabupaten Sambas)." AlBidayah: Jurnal Pendidikan Dasar Islam 9 (2): 147-56.

S Yusuf. 2016. Psikologi Perkembangan Anak dan Remaja. Bandung: PT Remaja Rosdakarya.

Santrock, John W. 2007. Perkembangan Anak. Jakarta: Erlangga. 
Subahri, Subahri. 2015. “Aktualisasi Akhlak Dalam Pendidikan.” Islamuna: Jurnal Studi Islam 2 (2): $167-82$.

Wina Sanjaya. 2013. Penelitian Pendidikan: Jenis, Metode, dan Prosedur. Jakarta: Kencana. 